Jurnal Laut Khatulistiwa, Vol. 4 No. 3 (October, 2021), Hal. 130-138.

ISSN : 2614-6142 (Printed), 2614-8005 (Online)

http://jurnal.untan.ac.id/index.php/lk

JURNAL LAUT

KHATULISTIWA

\title{
Struktur Komunitas Makrozoobentos di Pantai Gosong Kecamatan Sungai Raya Kepulauan Kabupaten Bengkayang Kalimantan Barat
}

\section{Structre of the Macrozoobenthos Commyity at Gosong Beach, Sungai Raya Kepulauan District Bengkayang Rengency West Kalimantan}

\author{
Joni Walbet Siahaan ${ }^{*}$, Warsidah ${ }^{2}$, Syarif Irwan Nurdiansyah ${ }^{2}$ \\ ${ }_{1}^{1}$ Program Studi Ilmu Kelautan, FMIPA Universitas Tanjungpura, Pontianak, Indonesia \\ ${ }^{2}$ Laboratorium Ilmu Kelautan, FMIPA Universitas Tanjungpura, Pontianak, Indonesia \\ ${ }^{*}$ E-mail : jonisiahaan90@gmail.com
}

Received : 17 July 2021; Accepted: 19 October 2021

Published: 31 October (C Author(s) 2021. This article is open access

\begin{abstract}
The beach is a common zone, one of which is used as a tourist spot by the local community/tourist and is a habitat for various organisms. The existence of community activities around Gosong Beach is at risk of affecting the ecosystem of biota that live in the area, one of which is macrozoobenthos. This study aims to determine the structure of the macrozoobenthos community in Gosong Beach, Sungai Raya Islands District, Bengkayang Regency. This research was conducted in November - April 2021. The sampling station was carried out by purposive sampling based on environmental baselines which consisted of three zones, namely the mangrove zone, the tourist zone, and the zone without settlements. Sampling macrozoobenthos using Ekman Grab and sampling random. The results of the study found 2 phyla, namely Mollusks and Echinoderms, which consisted of 3 classes (Bivalvia, Gastropods, Holothuroidea) and 11 species with a total of 132 individuals. Individual density values at the three stations ranged from 1,650-2,600 ind $/ \mathrm{m}^{2}$. The diversity index $\left(H^{\prime}\right)$ ranged from $0,716-1,534$. The uniformity index $(E)$ ranged from $0,445-0,738$. The dominance index (C) ranges from 0,430-0,679. Measurements of physico-chemical parameters of waters and substrates in Gosong Beach waters generally have a relatively homogeneous range in all observation stations and still support macrozoobenthos life.
\end{abstract}

Keywords : Community structure, Macrozoobenthos, West Kalimantan

\begin{abstract}
Abstrak
Pantai merupakan zona umum yang salah satunya dijadikan tempat wisata oleh masyarakat/wisatawan setempat serta menjadi habitat berbagai organisme. Adanya aktivitas masyarakat di sekitar Pantai Gosong beresiko mempengaruhi ekosistem biota yang hidup di kawasan tersebut, salah satunya makrozoobentos. Penelitian ini bertujuan untuk mengetahui struktur komunitas makrozoobentos di Pantai Gosong, Kecamatan Sungai Raya Kepulauan, Kabupaten Bengkayang. Penelitian ini telah dilakukan pada Bulan November - April 2021. Stasiun sampling dilakukan secara purposive sampling berdasarkan rona lingkungan yang terdiri dari tiga zona yaitu zona mangrove, zona wisata, zona tanpa pemukiman. Pengambilan sampel makrozoobentos menggunakan Ekman Grab dan pengambilan sampel dilakukan secara random. Hasil penelitian mendapatkan 2 filum yaitu Mollusca dan Echinodermata, yang terdiri atas 3 kelas yaitu (Bivalvia, Gastropoda, Holothuroidea) dan 11 spesies dengan jumlah 132 individu. Nilai kepadatan individu pada ketiga stasiun berkisar antara 1,650-2,600 ind $/ \mathrm{m}^{2}$. Indeks keanekaragaman $\left(\mathrm{H}^{\prime}\right)$ berkisar antara 0,716-1,534. Indeks keseragaman (E) berkisar antara 0,445-0,738. Indeks dominasi (C) berkisar antara 0,430-0,679. Pengukuran parameter fisika-kimia perairan dan substrat di perairan Pantai Gosong secara umum memiliki kisaran relatif homogen di seluruh stasiun pengamatan dan masih mendukung kehidupan makrozoobentos.
\end{abstract}

Kata kunci : Struktur komunitas, Makrozoobentos, Kalimantan Barat 


\section{Pendahuluan}

Pantai merupakan zona umum yang salah satunya dijadikan tempat wisata oleh masyarakat setempat dan wisatawan, serta menjadi habitat berbagai organisme, seperti ikan, udang dan sebagainya baik yang sifatnya menetap atau bergerak (Sitorus, 2008). Aktivitas masyarakat disekitar pesisir seringkali dikaitkan dengan kualitas perairan pesisir. Aktivitas yang banyak dilakukan oleh masyarakat adalah mengkonversi lahan pesisir menjadi lahan pemukiman, untuk memenuhi kebutuhan pasar, lahan pesisir banyak dikonversi menjadi lahan industri ataupun pertambakan. Pantai Gosong merupakan salah satu kawasan yang telah banyak mengalami konversi lahan menjadi kawasan pertambakan dan pemukiman.

Adanya aktifitas masyarakat di pesisir yang dapat mempengaruhi ekosistem biota yang hidup dikawasan tersebut, salah satunya makrozoobentos. Makrozoobentos merupakan organisme yang memiliki peran penting sebagai penyusun komunitas perairan (Suartini et al., 2007) dan merupakan sumber makanan berbagai jenis ikan (Zulkifli et al., 2009). Makrozoobentos merupakan suatu komunitas organisme laut yang mana sebagian siklus hidup dari makrozoobentos ini tinggal didasar perairan dimana sifat mereka hidup, baik yang menggali, merayap dan sesil (Yeanny, 2007).

Menurut Hartoni dan Agussalim (2013) moluska merupakan hewan lunak yang mempunyai cangkang. Moluska banyak ditemukan di ekosistem mangrove, hidup dipermukaan substrat maupun didalam substrat dan menempel pada pohon mangrove. Pergerakan makrozoobentos sangat terbatas dan relatif menetap pada satu substrat tertentu juga dapat digunakan untuk menduga kualitas atau ketidakseimbangan lingkungan fisika-kimia dan biologi perairan (Agustinus, 2013).

Makrozoobentos ini sangat mempunya peran penting dalam ekosistem diperairan dimana sebagai bioindikator lingkungan, bioturbasi sedimen yaitu perubahan struktur fisik tanah sebagai akibat perpindahan maupun pencampuran massa tanah yang dilakukan oleh organisme ini disebut bioturbasi (Lavelle dan Spain, 2005), dan pemakan bahan organik (Marmita et al., 2013)
Penelitian yang dilakukan Sidik (2016) ditemukan 18 jenis makrozoobentos yang tergolong dalam 3 kelas yaitu Gastropoda, Bivalvia dan Melocostraca di Kecamatan Susoh, Kabuapten Aceh Barat Daya. Arfianti (2019) Gastropoda Cerithium Granosum memiliki kelimpahan tertinggi dan tidak ditemukan makrozoobentos yang mendominasi di Kabupaten Lamongan, Jawa Timur dan Ulfah (2012) menemukan 25 jenis Polychaeta, Bivalvia, Gastropoda dan Crustacea di Desa Bedono, Kecamatan Sayung Demak.

Adanya aktivitas masyarakat atau pembangunan (Industri) di Pantai Gosong akan mempengaruhi kondisi perairan, sehingga secara tidak langsung akan mempengaruhi struktur komunitas komunitas makrozoobentos yang ada di perairan Pantai Gosong. Hal tersebut yang mendasari perlu dilakukakan penelitian ini untuk mengetahui struktur komunitas makrozoobentos di Pantai Gosong agar dapat dijadikan sumber informasi awal dalam rangka pelestarian keaneakarangaman hayati di pesisir Pantai Gosong.

\section{Metodologi Penelitian}

\subsection{Waktu dan Tempat Penelitian}

Penelitian dilaksanakan pada Bulan November 2020. Pengambilan sampel makrozoobentos dilakukan di perairan Pantai Gosong, Kecamatan sungai Raya Kepulauan, Kabupaten Bengkayang (Gambar 1). Pengamatan dan identifikasi dilakukan di Laboratorium Ilmu Kelautan, Fakultas Matematika dan Ilmu Pengetahuan Alam, Universitas Tanjungpura, Pontianak.

Penelitian ini menggunakan 2 tahap, yaitu survei lapangan (penentuan titik pengamatan dan pengambilan data), dan tahap analisis data. Titik pengambilan sampel ditentukan secara Purposive sampling berdasarkan rona lingkungan. Titik I berlokasi di zona mangrove, titik II berlokasi di zona pariwisata Pantai Gosong, dan titik III berlokasi di zona tanpa pemukiman.

\subsection{Pengambilan Data}

Sampel makrozoobentos diambil menggunakan Eckman Grab pada setiap titik 
Jurnal Laut Khatulistiwa, Vol. 4. No. 3 (October, 2021), Hal. 130-138.
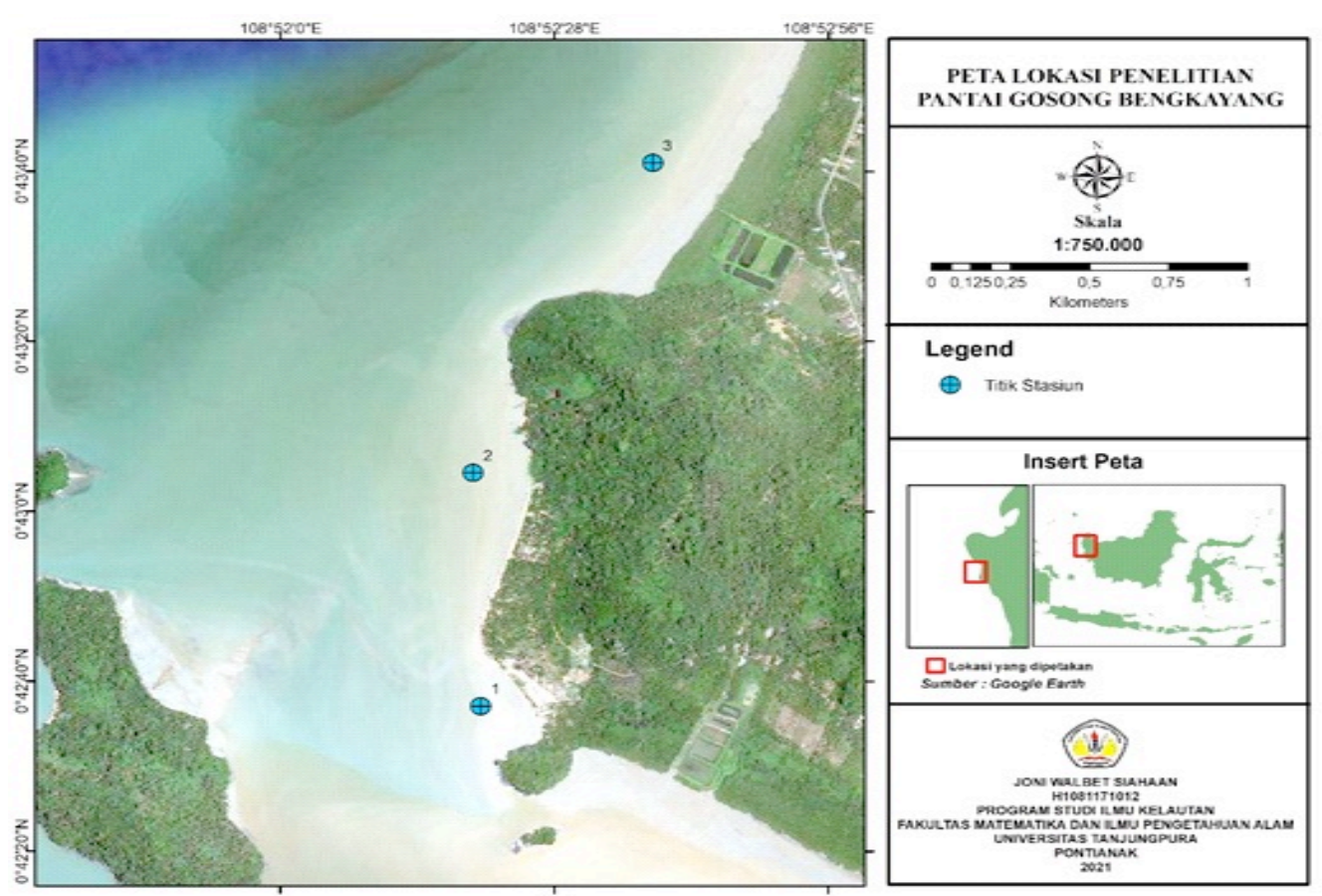

Gambar 1. Peta lokasi penelitian di Pantai Gosong

stasiun. Transek dibuat menggunakan aplikasi QGIS 3.10 (Gambar 2). Stasiun dibagi menjadi grid dimana setiap grid berukuran $5 \times 5 \mathrm{~m}$ menggunakan aplikasi QGIS 3.10, kemudian diberi penomoran grid 1-2,000. Pemilihan titik sampling dilakukan dengan mengacak nomor grid menggunakan metode tabel acak. Grid yang diambil setiap titik sampling sebanyak lima nomor, stasiun I $(20,52,159,250,299)$, stasiun II $(5,55,261,263,573)$ dan stasiun III (11, 167, 499, 732, 1056). Sampel diidentifikasi di Laboratorium Ilmu Kelautan, Fakultas Matematika dan Ilmu Pengetahuan Alam, Universitas Tanjungpura, Pontianak. Proses identifikasi dilakukan berdasarkan ciri morfologi menggunakanan acuan buku identifikasi yang ditulis oleh Dharma (1988) dan media online identification Bivalvia, Marine shell identification. Pengukuran Data Parameter Fisika dan Kimia yang diambil yaitu suhu, DO, salinitas, kedalaman, pH, substrat, dan kecepatan arus.

\subsection{Analisis Data}

Analisis data kepadatan makrozoobentos dihitung berdasarkan jumlah individu per satuan luas, dengan menggunakan rumus Shannon-Wiener :

$$
Y=a / b
$$

Dimana $\mathrm{Y}$ adalah Indeks kelimpahan (ind $/ \mathrm{m}^{2}$ ), a Jumlah makrozoobentos yang tersaring per jenis (ind), b Luas bukaan grab $\left(\mathrm{cm}^{2}\right)$

Kelimpahan Relatif dihitung menggunakan rumus Shannon-Wienner (Odum, 1993) yaitu :

$$
K r=n i / N \times 100 \%
$$

Dimana $\mathrm{Kr}$ adalah kelimpahan relatif, ni jumlah individu jenis ke-I dan $\mathrm{N}$ jumlah individu seluruh jenis.

Frekuensi kehadiran peluang ditemukannya suatu individu dalam semua petak.

$$
\begin{aligned}
& F K \\
& =\frac{\text { jumlah plot ditemukan suatu jenis }}{\text { jumlah total plot }}
\end{aligned}
$$

Indeks keanekaragaman dihitung menggunakan rumus Shannon-Wiener (Odum, 1971).

$$
H^{\prime}=-\sum P i \operatorname{Ln} P i
$$

Dimana H' adalah indeks keanekaragaman, $\mathrm{Pi}$ atau/N (perbandingan jumlah individu suatu jenis dengan jumlah individu keseluruhan jenis), $\mathrm{N}$ jumlah individu jenis ke$1, \mathrm{~N}$ jumlah total indivudu. 
Jurnal Laut Khatulistiwa, Vol. 4. No. 3 (October, 2021), Hal. 130-138.

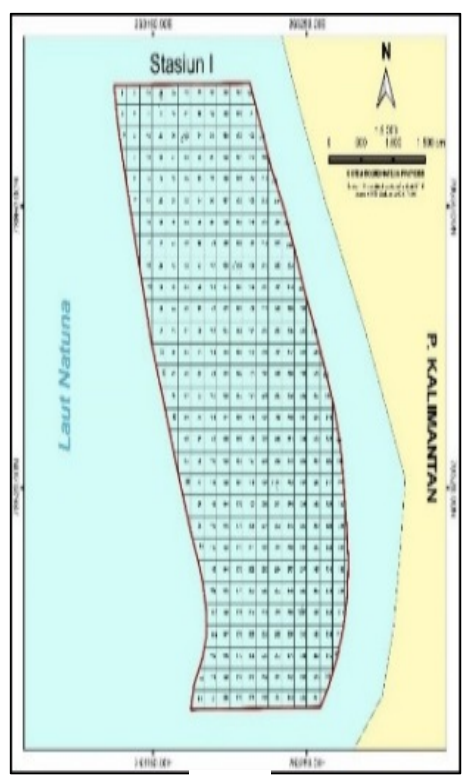

A

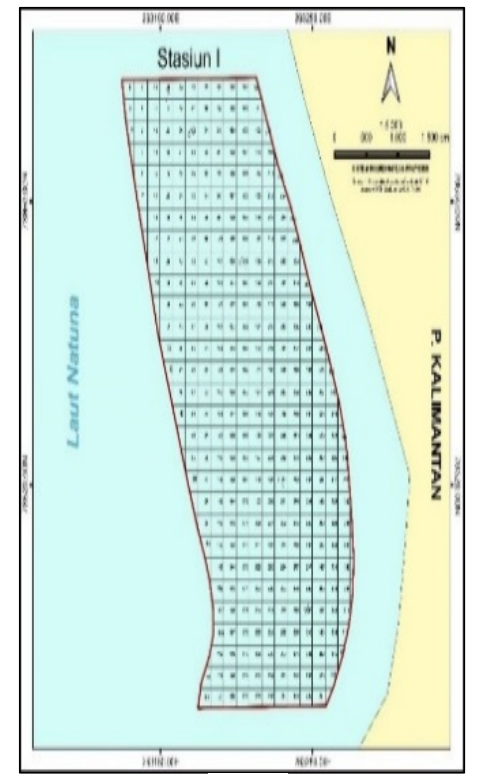

B

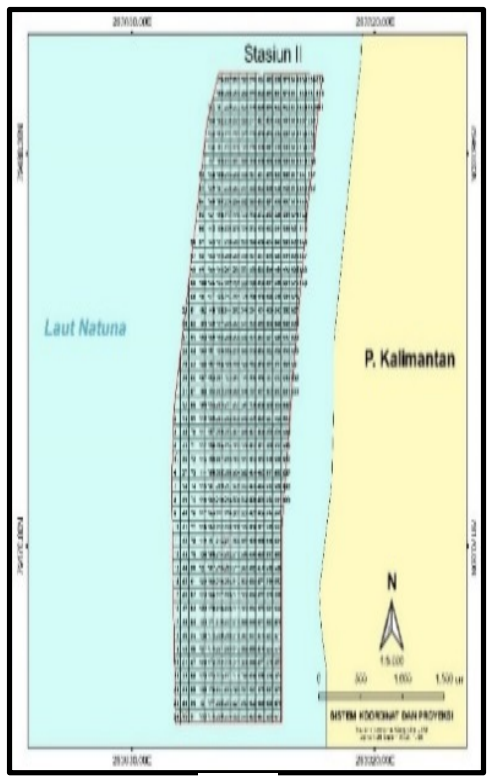

$\mathrm{C}$

Gambar 2. Sketsa grid acak yang digunakan dalam pengambilan sampel makrozoobentos. Lokasi A zona kawasan mangrove, lokasi B zona kawasan pariwisata, sedangkan lokasi C zona tanpa pemukiman.

Indeks keseragaman dihitung dengan menggunakan rumus Evennes - Indeks (Odum, 1993):

$$
E=H^{\prime} / \operatorname{InS}
$$

Dimana E adalah keseragaman jenis, $\mathrm{H}^{\prime}$ indeks keanekaragaman jenis, InS jumlah jenis organisme.

Indeks Dominasi dihitung dengan menggunakan rumus Dominance of Simpon (Odum, 1971):

$$
D=\sum[n i / N]^{2}
$$

Dimana D adalah indeks dominasi, ni jumlah individu setiap jenis, $\mathrm{N}$ jumlah total individu.

\section{Hasil dan Pembahasan}

\subsection{Komposisi Makrozoobentos Pantai Gosong}

Perairan Pantai Gosong, Kabupaten Bengkayang ditemukan 2 filum dan 3 kelas. Kedua filum yaitu Mollusca dan Echinodermata yang meliputi 3 kelas yaitu Bivalvia, Gastropoda dan Holothuroidea. Makrozoobentos yang ditemukan sebanyak 11 spesies dengan jumlah 132 individu yang tersebar pada ketiga stasiun
Makrozoobentos yang didapat pada lokasi penelitian dari kelas Bivalvia sebanyak 4 spesies dengan jumlah 106 individu pada ketiga stasiun. Spesies yang paling mendominasi diketiga stasiun yaitu spesies A. granosa dimana sesuai kondisi lingkungan yang ada di perairan Pantai Gosong substrat liat memungkinkan Bivalvia hidup pada substrat liat di dalam lumpur dan termasuk organisme deposit feeder (pemakan detritus), dimana detritus yang dihasilkan berasal dari masukan air sungai yang kemudian mengendap didasar perairan (Grey, 1981).

Makrozoobentos dari kelas Gastropda didapatkan 5 spesies dengan jumlah 24 individu pada ketiga stasiun dan spesies yang paling mendominasi yaitu spesies V. ampelusica. Spesies dari filum Gastropoda ini memiliki kaki berbentuk mendatar untuk bergerak dan memiliki kemampuan melekat kuat pada habitat yang bervariasi (Barnes, 1974).

Stasiun I berada pada zona kawasan mangrove memiliki komposisi makrozoobentos jumlah jenis sedang terdiri dari 7 spesies. Stasiun II yang berada pada zona kawasan pariwisata dengan komposisi makrozoobentos jumlah jenis rendah terdiri 5 spesies sementara stasiun III pada zona tanpa pemukiman memiliki komposisi 
Jurnal Laut Khatulistiwa, Vol. 4. No. 3 (October, 2021), Hal. 130-138.

Tabel 1. Keberadaan makrozoobentos yang ditemukan pada setiap stasiun

\begin{tabular}{|c|c|c|c|c|c|c|}
\hline \multirow{2}{*}{ Kingdom } & \multirow{2}{*}{ Filum } & \multirow{2}{*}{ Kelas } & \multirow{2}{*}{ Spesies } & \multicolumn{3}{|c|}{ komposisi } \\
\hline & & & & St I & St II & St III \\
\hline \multirow{11}{*}{ Animalia } & \multirow{8}{*}{ Mollusca } & \multirow{4}{*}{ Bivalvia } & Anadara Granosa & + & + & + \\
\hline & & & Anadara antiquata & - & - & + \\
\hline & & & Polymesoda erosa & + & + & + \\
\hline & & & Siliqua patula & - & + & - \\
\hline & & \multirow{4}{*}{ Gastropoda } & Volvarina ampelusica & + & + & + \\
\hline & & & Nerita peloronta & + & - & + \\
\hline & & & Pugilina cochlidium & - & - & + \\
\hline & & & Ocinebrina aciculata & + & + & + \\
\hline & \multirow{3}{*}{ Echinodermata } & \multirow{3}{*}{ Holothuroidea } & Tonna perdix & + & - & - \\
\hline & & & Paracaudina australis & + & - & - \\
\hline & & & Holothuria difficilis & - & - & + \\
\hline
\end{tabular}

makrozoobentos jumlah jenis tinggi dari ketiga stasiun yakni terdiri dari 8 spesies. Komposisi spesies makrozoobentos pada ketiga stasiun menunjukkan bahwa spesies yang paling banyak ditemukan pada stasiun adalah spesise A. granosa. Hal ini disebabkan kemampuan hewan ini dapat hidup pada perairan dengan substrat berpasir, lumpur, liat dan juga dengan kadar salinitas yang rendah (Pratama, 2015). Pernyataan tersebut sesuai dengan hasil pengamatan di lapangan hasil jenis substrat pada ketiga stasiun liat.

\subsection{Kepadatan (Idn/ $\mathbf{m}^{2}$ )}

Kepadatan tertinggi terdapat di stasiun III dengan nilai 2,600 ind $/ \mathrm{m}^{2}$ di ikuti dengan stasiun I dengan nilai $2,350 \mathrm{ind} / \mathrm{m}^{2}$ sedangkan stasiun II memiliki kepadatan terendah dengan nilai $1,650 \mathrm{ind} / \mathrm{m}^{2}$. Tinggi rendahnya keanekaragaman pada ketiga stasiun dikarenakan, stasiun I dan III yang berada pada kawasan mangrove memungkinkan makrozoobentos banyak ditemukan pada ekosistem tersebut sedangkan untuk stasiun II yang berada dikawasan Pantai Gosong (tempat wisata) memungkinkan terjadi tekanan ekologi atau faktor alam yang mengakibatkan makrozoobentos sulit beradaptasi pada kawasan tersebut. Berdasarkan Kurniawan et al. (2016) lokasi stasiun yang berada di pesisir pantai memungkinkan terjadi pengadukan yang cukup besar. Biota sulit beradaptasi pada stasiun tersebut dipengaruhi kedalaman dan kondisi perairan yang secara terus menerus mengalami perubahan menyebabkan biota sulit untuk beradaptasi di stasiun ini.

\subsection{Keanekaragaman}

\section{Makrozoobentos}

Indeks Keanekaragaman makrozoobentos yang didapat dari ketiga stasiun berkisar 0,716 - 1,534. Indeks Keanekaragaman pada lokasi penelitian tergolong rendah, Nybakken (1992) menyatakan bahwa rendahnya indeks keanekaragaman umunnya mengindikasikan bahwa perairan tersebut memiliki kualitas yang buruk.

Tingkat keanekaragaman yang rendah pada ketiga stasiun menunjukkan bahwa penyebaran individu tiap jenis cenderung tidak merata dan kondisi kestabilan komunitas yang cenderung rendah. Hal ini disebabkan semakin kecil jumlah spesies yang ditemukan dan adanya beberapa spesies yang jumlahnya lebih banyak menyebabkan terjadinya ketidakseimbangan ekosistem yang 
Jurnal Laut Khatulistiwa, Vol. 4. No. 3 (October, 2021), Hal. 130-138.

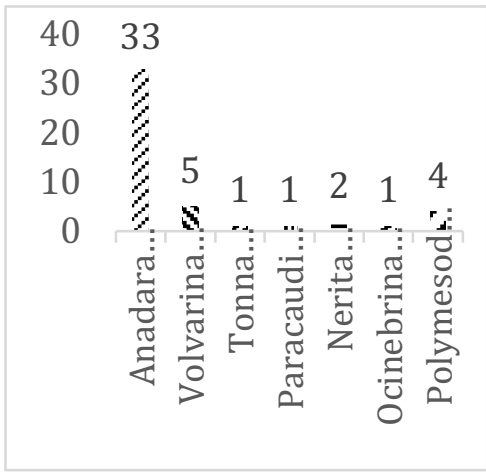

St. 1

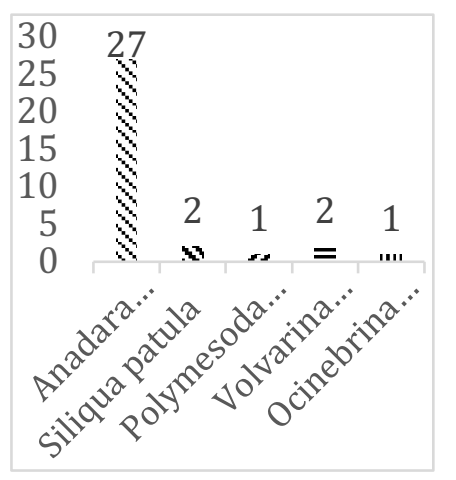

St. 2

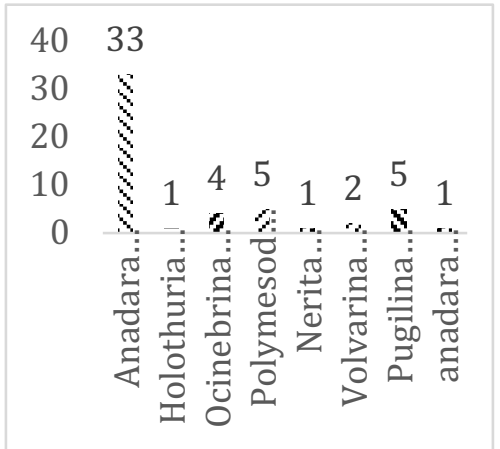

Gambar 3. Komposisi jenis makrozoobentos stasiun I berada pada zona mangrove, stasiun II zona parisiwisata, stasiun III zona tanpa pemukiman

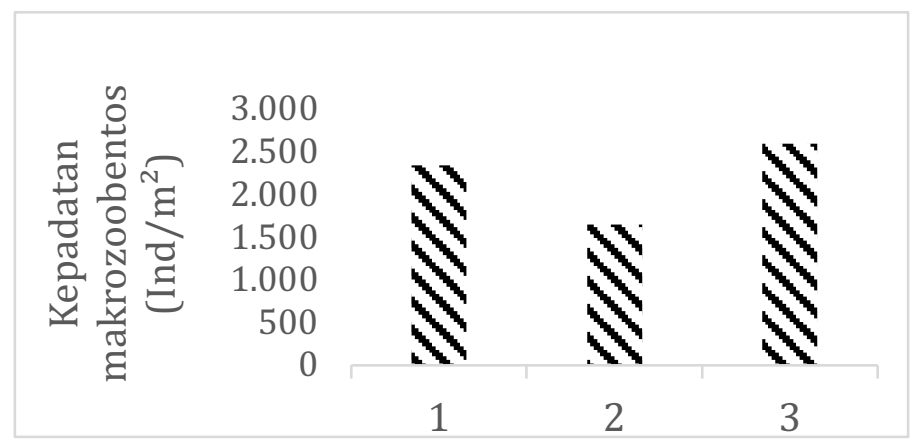

Gambar 4. Kepadatan makrozoobentos ind $/ \mathrm{m}^{2}$

kemungkinan disebabkan adanya tekanan ekologi atau gangguan dari lingkungan sekitar.

\subsection{Keseragaman (E) Makrozoobentos}

Stasiun I dan III memiliki nilai indeks keseragaman 0,553 dan 0,738 nilai tersebut menunjukkan tingkat keseragaman sedang sementara stasiun II menunjukkan nilai 0,445 dengan indeks keseragaman rendah. Stasiun I dan III nilai indeks keseragaman mendekati nilai 1 hal tersebut menunjukkan bahwa ekosistem tersebut berada dalam kondisi relative stabil, yaitu jumlah individu tiap spesies ralatif sam sementara stasiun II indeks keseragaman yang mendekati angka nilai 0 , hal tersebut menunjukkan bahwa penyebaran individu tiap spesies tidak sama dalam ekosistem tersebut terdapat kecenderungan terjadinya dominasi (Ferianita et al., 2005). Sementara stasiun yang memiliki nilai keseragaman rendah menggambarkan bahwa stasiun tersebut telah di dominasi oleh jenis tertentu yaitu spesies A. granosa.

\subsection{Dominasi (C) Makrozoobentos}

Indeks dominasi (C) yang ditemukan pada sasiun I 0,515 , stasiun II 0,679 dan stasiun III 0,430 . Jika nilai indeks dominasi mendekati satu berarti suatu komunitas didominasi oleh jenis tertentu sebaliknya jika nilai indeks dominasi mendekati nol berarti tidak ada yang dominan (Odum,1998).

Sesuai dengan kategori indeks dominasi Odum (1998) yang menunjukkan bahwa pada stasiun III tidak didominasi oleh jenis makrozoobentos tertentu dan masih tergolong

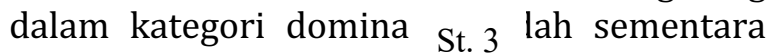
stasiun I dan II didomina: 3 ,enis A. granosa meski memiliki tingkat dominasi dalam kategori sedang ini dikarenakan jenis makrozoobentos ini merupakan kelas Bivalvia yang mampu hidup pada danau, waduk, sungai dan perairan tawar lainnya serta dengan 
Jurnal Laut Khatulistiwa, Vol. 4. No. 3 (October, 2021), Hal. 130-138.

Tabel 2. Nilai indeks keanekaragaman pada stasiun pengamatan

\begin{tabular}{ccl}
\hline Stasiun & $\mathrm{H}^{\prime}$ & Kategori \\
\hline I & 1,076 & Rendah \\
II & 0,716 & Rendah \\
III & 1,534 & Rendah \\
\hline
\end{tabular}

Tabel 3. Nilai indeks keseragaman pada stasiun pengamatan

\begin{tabular}{ccc}
\hline Stasiun & E & Kategori \\
\hline I & 0,553 & Sedang \\
II & 0,445 & Rendah \\
III & 0,738 & Sedang \\
\hline
\end{tabular}

Tabel 4. Nilai indeks dominasi pada stasiun pengamatan

\begin{tabular}{ccc}
\hline Stasiun & C & Kategori \\
\hline I & 0,515 & Sedang \\
II & 0,679 & Sedang \\
III & 0,430 & Rendah \\
\hline
\end{tabular}

kondisi substrat pasir dan berlumpur, dan juga jenis ini mampu bertahan hidup pada kondisi oksigen terlarut yang rendah dengan tingkat derajat keasaman $(\mathrm{pH})$ 4,8 - 9,8 dan suhu dengan kisaran $11-29^{\circ} \mathrm{C}$, hal ini sesuai dengan kondisi perairan pada stasiun penelitian.

\subsection{Parameter Fisika-Kimia di Perairan Pantai Gosong}

Suhu yang diperoleh diperairan Pantai Gosong pada ketiga stasiun masih tergolong normal untuk pertumbuhan makrozoobentos berkisar antara $25,6-28,8^{\circ} \mathrm{C}$. Rahmat (2009), suhu optimum umum untuk perkembangan makrozoobentos kisaran antara $20-30^{\circ} \mathrm{C}$.

Kandungan oksigen terlarut (DO) yang diperoleh pada ketiga stasiun berkisar antara 4,1 - 5,8 mg/L. Marpaung (2013) menyatakan bahwa kisaran (DO) perairan yang menunjang komunitas sampel makrozoobentos berkisar antara 4 - $6 \mathrm{mg} / \mathrm{L}$. Berdasarkan kategori hasil oksigen terlarut yang diperoleh masih dalam kondisi normal untuk menunjang kehidupan makrozoobentos.

Salinitas perairain Pantai Gosong masih berada dalam kategori normal atau tidak tercemar yaitu berkisar antara 27,6 - 38,7 ppt. Nilai salinitas umumnya bersifat alami dimana tinggi rendahnya hanya dipengaruhi oleh faktor cuaca dan alam. salinitas mempengaruhi laju pertumbuhan, jumlah makanan yang dikonsumsi dan daya kelangsungan hidup biota air (Yeanny, 2007).

Kedalaman perairan yang diperoleh selama penelitian masing-masing stasiun yaitu berkisar antara 0,55-1,15 m. Irmawan et al. (2010) Semakin dalam suatu perairan maka semakin sedikit jumlah makrozoobentos karena hanya makrozoobentos tertentu yang dapat beradaptasi dengan kondisi tertentu.

Nilai Derajat Keasaman $(\mathrm{pH})$ di perairan Pantai Gosong mempunyai nilai optimal bagi kehidupan makrozoobentos yang berkisar antara 7,43 - 7,91. Derajat keasaman merupakan salah satu faktor kualitas perairan 
Jurnal Laut Khatulistiwa, Vol. 4. No. 3 (October, 2021), Hal. 130-138.

Tabel 5. Parameter lingkungan di perairan Pantai Gosong, Bengkayang

\begin{tabular}{ccccc}
\hline \multirow{2}{*}{ No. } & Parameter & \multicolumn{3}{c}{ Stasiun } \\
\cline { 3 - 5 } & Optimum & St I & St II & St III \\
\hline \multirow{2}{*}{1} & Suhu & $25,6-27,1^{\circ} \mathrm{C}$ & $25,7-27,2^{\circ} \mathrm{C}$ & $25,6-28,8^{\circ} \mathrm{C}$ \\
2 & DO (mg/L) & $4,1-5,2 \mathrm{mg} / \mathrm{L}$ & $4,2-5,4 \mathrm{mg} / \mathrm{L}$ & $4,7-5,8 \mathrm{mg} / \mathrm{L}$ \\
3 & Salinitas (ppt) & $27,6-32,9$ & $34,3-38,5$ & $27,4-38,7$ \\
4 & Kedalaman (m) & 0,55 meter & 0,60 meter & 1,15 meter \\
5 & pH & $7,43-7,63$ & $7,48-7,79$ & $7,71-7,91$ \\
6 & Substrat & Liat & Liat & Liat \\
7 & Kecepatan Arus & $0,114 \mathrm{~m} / \mathrm{s}$ & $0,130 \mathrm{~m} / \mathrm{s}$ & $0,190 \mathrm{~m} / \mathrm{s}$ \\
\hline
\end{tabular}

yang juga berpengaruh terhadap kehidupan makrozoobentos (KepMen LH, 2004).

Tekstur substrat yang diperoleh dari hasil penelitian pada ketiga stasiun yaitu liat. Substrat merupakan salah satu faktor yang mempengaruhi struktur komunitas makrozoobentos (Wilhm, 1975) (Tabel. 5)

Kecepatan arus sangat menunjang kehidupan makrozoobentos karena merupakan sarana yang baik dalam transportasi makanan maupun oksigen bagi hewan makrozoobentos (Hawkes, 1978). Kecepatan arus yang diukur pada ketiga stasiun berkisaran nilai antara 0,114 - 0,190 $\mathrm{m} / \mathrm{s}$. Barus (2004) menyatakan bahwa kecepatan arus dipengaruhi kekuatan angin, topografi, kondisi pasang surut dan musim.

\section{Kesimpulan}

Makrozoobentos di perairan Pantai Gosong, Kabupaten Bengkayang ditemukan 2 filum yaitu Mollusca dan Echinodermata dan 3 kelas (Bivalvia, Gastropoda dan Holothuroidea) sementara hasil identifikasi mendapatkan 11 spesies dengan jumlah 132 individu yang tersebar pada ketiga stasiun. Indeks keanekaragaman $\left(\mathrm{H}^{\prime}\right)$ ketiga stasiun dikategorikan rendah, indeks keseragaman (E) pada stasiun I dan III dikategorikan sedang sementara stasiun II dikategorikan rendah, indeks dominasi (C) pada stasiun stasiun I dan II dikategorikan kedalam sedang karena mendekati nilai satu sementara stasiun III dikategorikan kedalam rendah karena mendekati nilai nol. Faktor kimia dan fisika yang mempengaruhi kehidupan makrozoobentos di kawasan Pantai Gosong antara lain suhu, $\mathrm{pH}$, salinitas, DO, substrat dan kecepatan arus.

\section{Daftar Pustaka}

Agustinus, Y., 2013, Struktur Komunitas Makrozoobenthos Sebagai Indikator Kualitas Perairan di Pulau Lengkang Kecamatan Belakang Padang Kota Batam Provinsi Kepulauan Riau. (Skripsi). Universitas Maritim Raja AliHaji.

Arfianti, D., 2019, Struktur Komunitas Makrozoobentos Pada Ekosistem Lamun Di Paciran, Kabupaten Lamongan, Jawa Timur. Journal of Fisheries and Marine Research, 3(1): 1 - 7.

Barnes, R.D., 1974. Invertebrate zoology. Third Edition. W. B. Saunders Company. Philadelphia. London. 317- 407 p.

Barus, T.A., 2004, Pengantar Limologi Studi Tentang Ekosistem Air Daratan. USU Press. Medan.

Dharma B., 1988, Siput dan Kerang Indonesia Indonesia Shell II. PT. Sarana Graha. Jakarta.

Ferianita-Fachrul, M., Haeruman, H.; Sitepu, L.C., 2005, Komunitas Fitoplankton Sebagai Bio-Indikator Kualitas PerairanTeluk Jakarta. Seminar Nasional MIPA 2005. UI Press; Jakarta.

Grey, J.S., 1981, The ecology of marine sediments. An Introduction to the 
Jurnal Laut Khatulistiwa, Vol. 4. No. 3 (October, 2021), Hal. 130-138.

Structure and Function of Benthic Communities. Cambridge University Press. London.

Hartoni., dan Agussalim, A., 2013, Komposisi dan Kelimpahan Moluska (Gastropoda dan Bivalvia) di Ekosistem Mangrove Muara Sungai Musi Kabupaten Banyuasin Provinsi Sumatera Selatan. Maspari Journal. 5 (1): 6 - 15

Hawkes, Y., 1978, Invertebrata As Indicator of River Water Quality: James and I. Evinson (Eds). Biological Indicator of Water Quality. John Wiley and Sons. Toronto. 123 pp.

Irmawan, R.N., 2010, Struktur Komunitas Makrozoobenthos di Estuaria Kuala Sugihan Provinsi Sumatra Selatan. Program Studi Kelautan FMIPA, Universitas Sriwijaya, Sumatra Selatan.

Keputusan Menteri Lingkungan Hidup No. 51 Tahun 2004, Tentang Baku Mutu Air Laut Untuk Biota.

Kurniawan, A.I.S., Purwiyanto., Fauziyah., 2016, Hubungan Nitrat, Fosfat dan Ammonium terhadap Keberadaan Makrozoobenthos di Perairan Muara Sungai Lumpur Kabupaten Ogan Komering Ilir Sumatera Selatan. Maspari Journal. 8(2): $101-110$

Lavelle, P., dan Spain, A.V., 2001, Soil ecology. Dordrecht: Kluwer Academic Publisher.

Marmita, R., Siahaan, R., Koneri, R., Langoy, M.L., 2013, Makrozoobenthos Sebagai Indicator Biologis Dalam Menentukan Kualitas Air Sungai Ranoyapo, Minahasa Selatan, Sulawesi Utara. J. Ilmiah Sains 13(1):58 - 61

Marpaung, A.A., 2013, Keanekaragaman Makrozoobenthos Di Ekosistem Mangrove Silvofishery Dan Mangrove Alami Kawasan Ekowisata Pantai Boe Kecamatan Galesong Kabupaten Takalar. Makasar:nUniversitas Hasanuddin Makasar.

Nybakken, J.W., 1992, Biologi Laut. Suatu Pendekatan Ekologis. Eidman, M., Koesoebiono, D.G. Begen, M. Hutomo, dan S. Sukardjo [Penerjemah]. Terjemahan dari: Marine Biology: An Ecological Approach. PT. Gramedia. Jakarta 3(2):133.

Odum, E.P., 1971, Dasar-Dasar Ekologi (3th end) (T. Samingan \& B.Srigandono). Yogyakarta: Gadjah Mada University Press.
Odum, E.P., 1993, Dasar-Dasar Ekologi. Edisi Ketiga. Gajah mada University Press. Jogjakarta. H.134- 162.

Odum, E.P., 1998, Dasar-dasar Ekologi. Gadjah Mada University Press. Yogyakarta. Indonesia.

Pratama, L.S., 2015, Keanekaragaman Kerang (Bivalvia) Di Zona Intertidal Teluk Pangpang Kecamatan Muncar Kabupaten Banyuwangi Dan Pemanfaatannya Sebagai Buku Suplemen. FKIP. Universitas Jember.

Rahman, F.A., 2009, Struktur Komunitas Makrozoobenthos di Perairan Estuaria Sungai Brantas (Sungai Porong dan Wonokromo), Jawa Timur. IPB. Bogor.

Sidik, R.Y., Dewiyanti, I., Octavina, C., 2016, Struktur Komunitas Makrozoobentos Dibeberapa Muara Sungai Kecamatan Susoh Kabupaten Aceh Barat Daya. Jurnal Ilmiah Mahasiswa Kelautan Dan Perikanan Unsyiah, 1(2), 287-296.

Suartini, N.M., Sudatri N.W., Pharmawati M., Raka Dalem, A.A.G., 2007, Identifikasi Makrozoobenthos di Desa Parerenan, Kabupaten Badung, Bali. Ecotrophic 5(1): 41-44.

Sitorus, D.BR., 2008, "Keanekaragaman dan Distribusi Bivalvia Serta Kaitannya dengan Faktor Fisik-Kimia di Perairan Pantai Labu Kabupaten Deli Serdang", Tesis Magister, Medan: Sekolah Pascasarjana Universitas Sumatera Utara, 9 - 11p.

Ulfah, Y., Zainuri, M., 2012, Struktur Komunitas Makrozoobenthos di Perairan Wilayah Morosari Desa Bedono Kecamatan Sayung Demak. Diponegoro Journal of Marine Research, 1(2), 188-196.

Wilhm, J.F., 1975, Biological Indicator of Pollution. London: Blackwel Scientific Publications.

Yeanny, S.M., 2007, Keanekaragaman Makrozoobentos di Muara Sungai Belawan. Jurnal Biologi Sumatra, No 2(2): 37-41.

Zulkifli, H., Zazili, H., Dian, A., 2009, Struktur dan Fungsi Komunitas Makrozoobentos di Perairan Sungai Musi Kota Palembang: Telaah Indikator pencemaran Air. Prosiding Seminar Nasional Biologi. 